\title{
Comparison of the Acute Erythropoietic Capacities of Erythropoietin and U-74389G Concerning Red Blood Cells Counts
}

\author{
Tsompos $\mathrm{C}^{1 *}$, Panoulis $\mathrm{C}^{2}$, Toutouzas $\mathrm{K}^{3}$, Triantafyllou $\mathrm{A}^{4}$, Zografos $\mathrm{GC}^{3}$ and Papalois $\mathrm{A}^{5}$ \\ ${ }^{1}$ Department of Gynecology, "Saint Dimitrios” General Hospital of Thessaloniki, Greece \\ ${ }^{2}$ Department of Obstetrics \& Gynecology, Athens University, Greece \\ ${ }^{3}$ Department of Surgery, Athens University, Greece \\ ${ }^{4}$ Department of Biologic Chemistry, Athens University, Greece \\ ${ }^{5}$ Experimental Research Centre ELPEN Pharmaceuticals, SA Inc, Greece
}

Submission: September 12, 2017; Published: November 07, 2017

*Corresponding author: Tsompos Constantinos, Department of Obstetrics \& Gynecology, Mesologi County Hospital, Nafpaktou street, Mesologi 30200, Etoloakarnania, Greece, Tel: 00302631360237, 00306946674264; Fax: 00302106811215; E-mail: Tsomposconstantinos@gmail.com

Abstract

Aim: This study compared the erythropoietic capacities of erythropoietin (Epo) and antioxidant drug U-74389G based on 2 preliminary studies. The provided results at red blood cells counts augmentation were co-evaluated in a hypoxia reoxygenation protocol of an animal model.

Materials and methods: Red blood cells (RBC) counts were evaluated at the 60th reoxygenation min (for groups A, C and E) and at the 120th reoxygenation min (for groups B, D and F) in 60 rats. Groups A and B received no drugs, rats from groups C and D were administered with Epo; whereas rats from groups $\mathrm{E}$ and $\mathrm{F}$ were administered with U-74389G.

Results: The first preliminary study of Epo non significantly increased the RBC counts by $0.80 \% \pm 0.01 \%$ ( $p$-value $=0.6446$ ). The second preliminary study of U-74389G also non significantly rised the RBC counts by $1.05 \% \pm 1.57 \%(\mathrm{P}=0.4911)$. These 2 studies were co-evaluated since they came from the same experimental setting. The outcome of the co-evaluation was that U-74389G has 1.309673-fold erythropoietic potency than Epo (p-value=0.0000).

Conclusion: The anti-oxidant capacities of U-74389G speed up the acute erythropoietic properties; presenting 1.309673-fold erythropoietic rise than epo ( $\mathrm{p}$-value $=0.0000)$.

Keywords: Hypoxia; Erythropoietin; U-74389G; Red blood cells counts; Reoxygenation

\section{Introduction}

The acute erythropoietic capacity of U-74389G is also non significant (p-value=0.4911) [1]. U-74389G is a novel antioxidant factor. It implicates just only 255 known biomedical studies at present. $4.31 \%$ of these studies concern tissue hypoxia and reoxygenation (HR) experiments. The promising effect of U-74389G in tissue protection has been noted in these HR studies. U-74389G or also known as 21-[4-(2,6-di-1pyrrolidinyl-4-pyrimidinyl)-1-piperazinyl]-pregna-1,4,9(11)triene-3,20-dione maleate salt is an antioxidant which prevents both arachidonic acid-induced and iron-dependent lipid peroxidation. It protects against HR injury in animal heart, liver and kidney models. These membrane-associating antioxidants are particularly effective in preventing permeability changes in brain microvascular endothelial cells monolayers. Lazaroids, a novel series of glucocorticoid compounds 21-aminosteroids have the properties of free radical scavenging. U-74389G is one of the 132 similar lazaroid compounds. It has a molecular weight of $726.90406 \mathrm{~g} / \mathrm{mol}$; it has a selective action on vascular endothelium with vitamin E-like properties.

However, the erythropoietic capacity of U-74389G gets more comprehensible whether is compared with the same capacity of a standard known drug. Such one of the most well studied drug; actually with original erythropoietic capacity ( $p$-value $=0.6446$ ) is erythropoietin (Epo). Indeed, Epo implicates over 29,675 known biomedical studies at present. $10.47 \%$ at least of these studies concern tissue hypoxia and reoxygenation (HR) 
experiments. Certainly, the concept has been moved away from the original action of Epo in stem blood cells recovery. However, just few related reports were found, not covering completely the specific matter with antioxidant factors. The special aim of this experimental work was to compare the acute erythropoietic capacities of U-74389G and Epo on a rat model and mainly in an HR protocol. Their effects were tested by measuring the red blood cells (RBC) counts.

\section{Materials and Methods}

\section{Animal preparation}

The Vet licenses of the research were provided under 3693/12-11- 2010 \& 14/10-1-2012 decisions. The granting company and the place of experiment are mentioned in related references [1,2]. Appropriate humanistic care was adopted for Albino female Wistar rats. 7 days pre-experimental normal housing included ad libitum diet in laboratory. Continuous intra-experimental general anesthesia, oxygen supply, electrocardiogram, acidometry and post-experimental euthanasia were provided. Rats 16-18 weeks old were randomly delivered to six (6) groups ( $\mathrm{n}=10$ ), using the following protocols of HR: Hypoxia for $45 \mathrm{~min}$ followed by reoxygenation for $60 \mathrm{~min}$ (group A); hypoxia for $45 \mathrm{~min}$ followed by reoxygenation for 120 min (group B); hypoxia for $45 \mathrm{~min}$ followed by immediate Epo intravenous (IV) administration and reoxygenation for $60 \mathrm{~min}$ (group C); hypoxia for $45 \mathrm{~min}$ followed by immediate Epo IV administration and reoxygenation for $120 \mathrm{~min}$ (group D); hypoxia for $45 \mathrm{~min}$ followed by immediate U-74389G intravenous (IV) administration and reoxygenation for 60 min (group E); hypoxia for $45 \mathrm{~min}$ followed by immediate U-74389G IV administration and reoxygenation for $120 \mathrm{~min}$ (group F). The dose height selection criteria of Epo and U-74389G were assessed at preliminary studies as $10 \mathrm{mg} / \mathrm{Kg}$ body mass of animals for both drugs.

Hypoxia was caused by laparotomic clamping inferior aorta over renal arteries with forceps for $45 \mathrm{~min}$. The clamp removal was restoring the inferior aorta patency and reoxygenation. After exclusion of the blood flow, the protocol of HR was applied, as described above for each experimental group. The drugs were administered at the time of reperfusion; through inferior vena cava catheter. The RBC counts were determined at 60thmin of reoxygenation (for $\mathrm{A}, \mathrm{C}$ and $\mathrm{E}$ groups) and at 120thmin of reoxygenation (for $\mathrm{B}, \mathrm{D}$ and $\mathrm{F}$ groups).The animals' mass was not a confusing factor for RBC counts ( $\mathrm{p}$-value=0.5048).

\section{Statistical analysis}

Table 1 presents the (\%) augmentation influence of Epo regarding reoxygenation time. Also, Table 2 presents the (\%) augmentation influence of U-74389G regarding reoxygenation time. Chi-square tests were applied using the ratios which produced the $(\%)$ results per endpoint. The outcomes of chisquare tests are depicted at Table 3 . The statistical analysis was performed by Stata 6.0 software [Stata 6.0, StataCorp LP, Texas, USA].

Table 1: The (\%) augmentation influence of erythropoietin in connection with reoxygenation time.

\begin{tabular}{|c|c|c|c|}
\hline Change & $\mathbf{\pm S D}$ & Reoxygenation time & p-values \\
\hline $1.45 \%$ & $\pm 3.84 \%$ & $1 \mathrm{~h}$ & 0.6589 \\
\hline $0.37 \%$ & $\pm 2.98 \%$ & $1.5 \mathrm{~h}$ & 0.9048 \\
\hline$-0.70 \%$ & $\pm 6.07 \%$ & $2 \mathrm{~h}$ & 0.8844 \\
\hline $4.47 \%$ & $\pm 2.89 \%$ & reoxygenation time & 0.1239 \\
\hline $0.80 \%$ & $\pm 0.01 \%$ & interaction & 0.6446 \\
\hline
\end{tabular}

Table 2: The (\%) augmentation influence of U-74389G in connection with reoxygenation time.

\begin{tabular}{|c|c|c|c|}
\hline Augmentation & \pm SD & Reoxygenation time & p-value \\
\hline $1.39 \%$ & $\pm 4.67 \%$ & $1 \mathrm{~h}$ & 0.7161 \\
\hline $0.64 \%$ & $\pm 2.62 \%$ & $1.5 \mathrm{~h}$ & 0.8106 \\
\hline$-0.10 \%$ & $\pm 4.37 \%$ & $2 \mathrm{~h}$ & 0.9762 \\
\hline $4.65 \%$ & $\pm 2.5 \%$ & reoxygenation time & 0.068 \\
\hline $1.05 \%$ & $\pm 1.57 \%$ & interaction & 0.4911 \\
\hline
\end{tabular}

Table 3: The U-74389G / erythropoietin efficacies ratios on RBC counts augmentation after chi-square tests application.

\begin{tabular}{|c|c|c|c|c|}
\hline Odds ratio & \multicolumn{2}{|c|}{ (95\% Conf. Interval) } & p-values & Endpoint \\
\hline 0.961059 & 0.958379 & 0.963746 & 0 & $1 \mathrm{~h}$ \\
\hline 1.733395 & 1.724921 & 1.74191 & 0 & $1.5 \mathrm{~h}$ \\
\hline 6.519657 & 6.4712605 & 6.568412 & 0 & $2 \mathrm{~h}$ \\
\hline 1.039524 & 1.037862 & 1.04119 & 0 & reperfusion time \\
\hline 1.309673 & 1.305082 & 1.314281 & & interaction \\
\hline
\end{tabular}




\section{Results}

The successive application of chi-square tests revealed that U-74389G favored erythropoiesis by 0.9610586 -fold (0.9583790.9637456) than Epo at $1 \mathrm{~h}$, by 1.733395-fold (1.724921$1.74191)$ at $1.5 \mathrm{~h}$, by 6.5196571 -fold (6.4712605-6.568412) at 2h, by 1.039524 -fold (1.037862-1.04119) without drugs and by 1.309673-fold (1.305082-1.314281) whether all variables have been considered $(\mathrm{p}$-value $=0.0000)$.

\section{Discussion}

The unique available study investigating the rising effect of U-74389G on RBC counts was the preliminary one [1]. Although the most famous activities of neuroprotection and membranestabilization properties, it accumulates in the cell membrane, protecting vascular endothelium from peroxidative damage but hardly penetrates the blood-brain barrier. It elicits a beneficial effect in ototoxicity and Duchenne muscular dystrophy. It increases $\gamma$ GT, SOD, and GSH levels in oxygen-exposed cells. It treats septic states and acts as immunosuppressant in flap survival. It prevents the learning impairments, it delays the early synaptic transmission decay during hypoxia improving energetic state of neurons. It shows anti proliferative properties on brain cancer cells and is considered as a new promising anti inflammatory drug for the treatment of reperfusion syndrome in IR injuries.

The same authors generally confirmed [2] the short-term or long-term erythropoietic effect of various Epo preparations in 9 IR laboratory or clinical biomedical studies on human individuals or animals tried to stimulate erythropoiesis as the speedy replacement of blood loss with endogenous red blood cells [3]. Denny ended [4] up that the hypoxia-inducible transcription factor (HIF) stimulates the production of Epo and ultimately RBC count. [5] Controlled the development of RBC count from committed progenitors, with the Epo-receptor (Epo-R) signaling network being the primary controlling molecular hub. Soliz. agreed that [6] Epo as a cytokine able to increase the production of RBC count upon conditions of reduced oxygen availability [7] to Epo-mediated elevation of RBC count through increased minute ventilation and tissue oxygenation. Guo [8] associated a greater increase in reticulocyte count with hepatic hepcidin mRNA expression down-regulation, with renal Epo mRNA expression up-regulation, increased Epo levels and erythrocytosis. [9] exemplified Epo as a plasma protein that can initiate the feedback production of new RBC. [10] demonstrated that stabilization of hypoxia inducible factor (HIF) can up-regulate Epo expression and in turn increase count of RBCs potentially exemplified the demethylation of the Epo enhancer region [11] as key regulator in the production of RBCs. [12] related the increase in plasma Epo with the nucleated RBCs (NRBC); but not with the 'emergence time, the NRBC first appeared in the blood between 24 and $36 \mathrm{~h}$ after any dose in neonates. [13] described human Epo as a $30.4 \mathrm{k}$ Da glycoprotein hormone composed of a single 165 amino acid residues chain to which four glycans are attached; being an essential factor for the viability and proliferation of erythrocytic progenitors. Jelkmann [14] calculated a delayed way, this is, a lag of 3-4 days for erythropoiesis-stimulating agents (ESAs) to act in inducing an increase in reticulocytes [15]. Significantly decreased erythropoiesis in Ret \% by $41.66 \%, 7-10$ day after HT which eliminated the major gene regulating Epo/ synthesis; the hypoxia- induced factor (HIF) expression [16] considered Epo as a key mediator in increasing the RBC count during hypoxia [17]. Revealed that decreased expression levels of hypoxia inducible factor 1 and its down-stream target genes Epo is responsible for the generation of senescent erythrocytes and RBC in chronodisrupted animals [18]. Indicated the activation of erythropoiesis during the first 7 days of hypoxia which induces an increase in peripheral RBC (polycythemia) caused by an increased Epo production. Kaliev [19]. Increased the RBC concentration indices in patients receiving Epo. [20] found that acute hypoxia stimulates large increases in serum Epo which induces formation of characteristic enlarged RBCs with maximum elevations 1month after onset [21] observed 1,000 fold increase in Epo mRNA and 2-3-fold increase in the reticulocytes at orally administered $30 \mathrm{mg} / \mathrm{kg}$ of a small molecule inhibitor (PHI-1) of prolyl-hydroxylase-2 (PHD2) enzyme involved in regulating HIF$1 \alpha$ levels in male BALB/c mice [22]. Up-regulated the hypoxic marker genes hypoxia inducible factor $1 \alpha$, myoglobin 1 , and Epo 2 significantly increasing the production of immature RBC in fish [23] led to increased Epo expression which activates production of RBC after hypoxia-inducible transcription factors stabilization. [24] caused hypoxia which increased Epo expression higher than $70 \%$ being responsible for regulating the $\mathrm{RBC}$ growth and development in $\mathrm{C} 2 \mathrm{C} 12$ myoblasts, myotubes, and primary myoblasts in vitro than unexercised controls [25]. Found a dose-dependent increase in RBC count in rHuEP0200, rHuEPO400 and rHuEP0600 therapy groups whereas increase in reticulocyte count only in rHuEPO400 and rHuEPO600 therapy groups in male Wistar rats [26]. induced slowed maturation of $\mathrm{RBC}$ in the bone marrow inhibiting hepsidin production, after Epo release and erythropoiesis activation. [27] Repeated that the glycoprotein Epo promotes the production of RBCs. Urrutia AA [28]. determined that brain pericytes represent an up to $70 \%$ cellular source of Epo in the hypoxic brain of all Epo-expressing cells and thus an increased RBC production due to HIF-mediated induction of Epo in mice with genetic HIF activation [29]. Significantly correlated the Epo cord blood and NRBC with maternal BMI [30]. Accentuated the well-known role of Epo in RBC production. Haddad [31]. Examined the effect of intraperitoneal injections of $40 \mathrm{mg} / \mathrm{kg}$ of the lazaroid compound U-74389G every 12 hours, on acute otitis media in guinea pigs. Streptococcus pneumoniae organisms were inoculated into the right tympanic cavity; with the left ear served as a control [32].

According to above, Table 3 shows that U-74389G speeds up by 1.309673 -fold (1.305082-1.314281) the erythropoietic potency than Epo (p-value=0.0000); a trend augmented along 


\section{Juniper Online Journal Material Science}

time, in Epo non-deficient rats. A meta-analysis of these ratios provides comparable results (Table 4 \& 5).

from the same experiment, for 2 other hematologic variables,

Table 4: A U-74389G/ erythropoietin efficacies ratios meta-analysis on 5 hematologic variables ( 3 variables with balancing efficacies and 2 variables with opposite efficacies).

\begin{tabular}{|c|c|c|c|c|c|c|c|c|c|c|}
\hline $\begin{array}{l}\text { Endpoint } \\
\text { Variable }\end{array}$ & $1 \mathrm{~h}$ & p-value & $1.5 \mathrm{~h}$ & p-value & $2 \mathrm{~h}$ & p-value & $\begin{array}{c}\text { Reperfusion } \\
\text { time }\end{array}$ & p-value & interaction & p-value \\
\hline Hematocrit & 38.424 & 0.0000 & 9.076658 & 0.0000 & 6.222898 & 0.0000 & 1.001356 & 0.2184 & 12.66419 & 0.0000 \\
\hline Hemoglobin & 1.268689 & 0.0000 & 1.839035 & 0.0000 & 13.1658 & 0.0000 & 1.252422 & 0.0000 & 1.94889 & 0.0000 \\
\hline Creatinine & 168.9034 & 0.0000 & 4.872332 & 0.0000 & 3.039572 & 0.0000 & 1.0262016 & 0.0000 & 5.005523 & 0.0000 \\
\hline Mean & 20.1929009 & 0.0000 & 4.33262345 & 0.0000 & 6.29145057 & 0.0000 & 1.08773713 & 0.0728 & 4.98048231 & 0.0000 \\
\hline
\end{tabular}

Table 5: A U-74389G/ erythropoietin efficacies ratios meta-analysis on 5 hematologic variables (3 variables with balancing efficacies and 2 variables with opposite efficacies) [32].

\begin{tabular}{|c|c|c|c|c|c|c|c|c|c|c|}
\hline $\begin{array}{l}\text { Endpoint } \\
\text { Variable }\end{array}$ & $1 \mathrm{~h}$ & p-value & $1.5 \mathrm{~h}$ & p-value & $2 \mathrm{~h}$ & p-value & $\begin{array}{c}\text { Reperfusion } \\
\text { time }\end{array}$ & p-value & interaction & $p$-value \\
\hline $\begin{array}{c}\text { Mean } \\
\text { corpuscular } \\
\text { hemoglobin } \\
\text { concentrations }\end{array}$ & -0.2774225 & 0 & -0.5504722 & 0 & -0.8522433 & 0 & 3.044774 & 0 & -0.7793243 & 0 \\
\hline Platelet crit & -0.2312044 & 0 & -0.6719365 & 0 & -1.330756 & 0.0886 & 5.620077 & 0 & -0.9771515 & 0 \\
\hline Mean & $-0,2532076$ & 0 & $-0,6081795$ & 0 & $-10,649,544$ & 0.0443 & $41,366,488$ & 0 & $-0,8726499$ & 0 \\
\hline
\end{tabular}

\section{Conclusion}

The anti-oxidant capacities of U-74389G speed up by 1.309673-fold (1.305082-1.314281) the erythropoietic potency than Epo (p-value=0.0000) in Epo non-deficient rats ( $p$-value $=0.0000$ ). This trend is enhanced along the short term time frame of the experiment.

\section{References}

1. Tsompos C, Panoulis C, Toutouzas K, Zografos G, Papalois A (2014) The effect of the antioxidant drug U-74389G on red blood cells levels during ischemia reperfusion injury in rats. Journal of Acute disease: 320-323.

2. Tsompos C, Panoulis C, Toutouzas K, Zografos G, Papalois A (2016) The Acute Effect of Erythropoietin on Red Blood Cells Count During Hypoxia Reoxygenation in Rats. Literati Journal of Pharmaceutical Drug Delivery Technologies 2(1): 3-7.

3. Simoni J, Simoni G, Moeller JF, Feola M, Griswold JA, et al. (2012) Adenosine-5'-triphosphate-adenosine-glutathione cross-linked hemoglobin as erythropoiesis-stimulating agent. Artif Organs 36(2): 139-150.

4. Denny WA (2012) Giving anemia a boost with inhibitors of prolyl hydroxylase. J Med Chem 55(7): 2943-2944.

5. Ingley E (2012) Integrating novel signaling pathways involved in erythropoiesis. IUBMB Life 64(5): 402-410.

6. Soliz J (2013) Erythropoietin and respiratory control at adulthood and during early postnatal life. Respir Physiol Neurobiol 185(1): 87-93.

7. Soliz J, Khemiri H, Caravagna C, Seaborn T (2012) Erythropoietin and the sex-dimorphic chemoreflex pathway. Adv Exp Med Biol 758: 55-62.

8. Guo W, Bachman E, Li M, Roy CN, Blusztajn J, et al. (2013) Testosterone administration inhibits hepcidin transcription and is associated with increased iron incorporation into red blood cells. Aging Cell 12(2):
280-291.

9. Carter PR, Watts MN, Kosloski-Davidson M, Prasai K, Grisham MB, et al. (2013) Iron status, anemia, and plasma erythropoietin levels in acute and chronic mouse models of colitis. Inflamm Bowel Dis 19(6): 12601265.

10. Zhao S, Wu J (2013) Hypoxia inducible factor stabilization as a novel strategy to treat anemia. Curr Med Chem 20(21): 2697-2711.

11. Dewi FR, Fatchiyah F (2013) Methylation impact analysis of erythropoietin (EPO) Gene to hypoxia inducible factor-1 $\alpha$ (HIF-1 $\alpha$ ) activity. Bioinformation 9(15): 782-787.

12. Christensen RD, Lambert DK, Richards DS (2014) Estimating the nucleated red blood cell 'emergence time' in neonates. J Perinatol 34(2): 116-119.

13. Jelkmann W (2013) Physiology and pharmacology of erythropoietin. Transfus Med Hemother 40(5): 302-309.

14. Jelkmann I, Jelkmann W (2013) Impact of erythropoietin on intensive care unit patients. Transfus Med Hemother 40(5): 310-318.

15. Pramatarova T, Yarakova N, Sluncheva B, Hitrova S, Radulova P, et al. (2013) Blood transfusions suppress erythropoiesis in anemia of prematurity. Akush Ginekol (Sofiia) 52(5): 42-46.

16. Feizi H, Rajaee K, Keyhanmanesh R, Aliparasti MR, Almasi S, et al. (2014) Effect of ghrelin on renal erythropoietin production in chronic hypoxic rats. Endocr Regul 48(1): 3-8.

17. Egg M, Paulitsch M, Ennemoser Y, Wüstenhagen A, Schwerte T, et al. (2014) Chronodisruption increases cardiovascular risk in zebrafish via reduced clearance of senescent erythrocytes. Chronobiol Int 31(5): 680-689.

18. Harada T, Tsuboi I, Hirabayashi Y, Kosaku K, Naito M, et al. (2015) Decreased "ineffective erythropoiesis" preserves polycythemia in mice under long-term hypoxia. Clin Exp Med 15(2): 179-188. 
19. Kaliev R, Murkamilov IT, Fomin VV, Kaliev KP, Aver'ianova NI (2014) Effect of erythropoietin and its combination with hypoxic altitude chamber training on the clinical and functional manifestations of chronic glomerulonephritis. Ter Arkh 86(10):40-46.

20. Yčas JW, Horrow JC, Horne BD (2015) Persistent increase in red cell size distribution width after acute diseases: A biomarker of hypoxemia? Clin Chim Acta 448: 107-117.

21. Singh I, Nagiec EE, Thompson JM, Krzyzanski W, Singh P (2015) A systems Pharmacology Model of Erythropoiesis in Mice Induced by Small Molecule Inhibitor of Prolyl Hydroxylase Enzymes. CPT Pharmacometrics Syst Pharmacol 4(2): e12.

22. Tasaki J, Nakayama K, Shimizu I, Yamada H, Suzuki T, et al. (2017) Nishiyama N, Yamane M. Cellular and molecular hypoxic response in common carp (Cyprinus carpio) exposed to linear alkylbenzene sulfonate at sublethal concentrations. Environ Toxicol 32(1): 122-130.

23. Kinobe RT (2016) Towards the elimination of excessive cobalt supplementation in racing horses: A pharmacological review. Res Vet Sci 104: 106-112.

24. Baker JM, Parise G (2016) Skeletal Muscle Erythropoietin Expression Is Responsive to Hypoxia and Exercise. Med Sci Sports Exerc 48(7): 1294-1301.

25. Ribeiro S, Garrido P, Fernandes J, Vala H, Rocha-Pereira P, et al. (2016) Impaired renal endothelial nitric oxide synthase and reticulocyte production as modulators of hypertension induced by rHuEPO in the rat. Life Sci 151: 147-156.
26. Budnevsky AV, Esaulenko IE, Ovsyannikov ES, Labzhaniya NB, Voronina EV, et al. (2016) Chernov AV. ANEMIC SYNDROME IN PATIENTS WITH COMMUNITY-ACQUIRED PNEUMONIA. Klin Med Mosk 94(1): 56-60.

27. Jelkmann W (2016) Erythropoietin. Front Horm Res 47: 115-127.

28. Urrutia AA, Afzal A, Nelson J, Davidoff O, Gross KW, et al. (2016) Prolyl4-hydroxylase 2 and 3 coregulate murine erythropoietin in brain pericytes. Blood 128(21): 2550-2560.

29. Ibrahim MH, Moustafa AN, Saedii AAF, Hassan EE (2016) Cord Blood Erythropoietin and Cord Blood Nucleated Red Blood Cells for Prediction of Adverse Neonatal Outcome Associated with Maternal Obesity in Term Pregnancy: Prospective cohort study. J Matern Fetal Neonatal Med 3: 1-20.

30. Pichon A, Jeton F, El Hasnaoui-Saadani R, Hagström L, Launay T, et al. (2016) Beaudry M, Marchant D, Quidu P, Macarlupu JL, Favret F, Richalet JP, Voituron N. Erythropoietin and the use of a transgenic model of erythropoietin-deficient mice. Hypoxia (Auckl) 4: 29-39.

31. Haddad J Jr, Egusa K, Takoudes TG (1998) Effects of 21-aminosteroid U-74389G on acute otitis media in a guinea pig model. Otolaryngol Head Neck Surg 118(1): 44-48.

32. Tsompos C, Panoulis C, Toutouzas K, Zografos G, Papalois A (2017) Investigation of the Opposite Capacities of Erythropoietin and U-74389G on Platelet Crit Levels. Mod Appro Drug Des 1(1).

\begin{tabular}{|l|}
\hline \multicolumn{1}{|c|}{ Your next submission with Juniper Publishers } \\
will reach you the below assets \\
- Quality Editorial service \\
- Swift Peer Review \\
- Reprints availability \\
- E-prints Service \\
- Manuscript Podcast for convenient understanding \\
- Global attainment for your research \\
- Manuscript accessibility in different formats \\
( Pdf, E-pub, Full Text, Audio) \\
- Unceasing customer service \\
Track the below URL for one-step submission \\
https://juniperpublishers.com/online-submission.php
\end{tabular}

